\title{
Erfðabreytt matvæli: ógn við heilsu?
}

\section{Magnús Karl Magnússon}

Höfundur er prófessor i lyfjaog eiturefnafræði og forstöðumaður rannsóknarstofu í lyfja- og eiturefnafræði, læknadeild Háskóla Íslands.

magnuskm@hi.is

Í síðasta mánuði birtist grein í tímaritinu Food and Chemical Toxicology par sem pví var haldið fram að erfðabreyttur maís og illgresiseyðirinn glyfosat tengdust myndun stórra og oft illkynja æxla og snemmbærum dauða í rottum. ${ }^{1}$ Greinin vakti gríðarlega athygli í fjölmiðlum um allan heim enda málefnið umdeilt meðal almennings og ýmissa grasrótarsamtaka. Ekki var liðinn langur tími par til efasemdaraddir fóru að heyrast frá vísindamönnum um allan heim sem höfðu kynnt sér rannsóknarniðurstöðurnar. Gagnrýni vísindamanna var einróma. Vísindagreinin stóðst engan veginn pær kröfur sem gerðar eru til ritrýndra vísindaverka, en skaðinn var skeður. Tekist hafði að skapa tortryggni hjá almenningi. Hópurinn sem stóð að pessari rannsókn meinaði blaðamönnum að leita álits vísindamanna á efni greinarinnar fyrir útgáfu, pvert á hefðbundnar samskiptareglur vísinda- og blaðamanna í slíkum málum. Útgáfu vísindagreinarinnar var einnig fylgt úr hlaði með frumsýningu á heimildarmynd um skaðsemi erfðabreyttra plantna. Slíkt verður að teljast harla óvenjulegt pegar vísindaniðurstöður af pessu tagi eru birtar.

En hvað var athugavert við pessa umdeildu rannsókn? Pað er raunar svo margt að ekki er hægt að útlista svo vel sé í stuttu máli. Helst hefur verið bent á lítinn hóp samanburðardýra og algeran skort á tölfræðilegri greiningu á tíðni æxlismyndunar eða snemmbærs dauða í meðferðarhópum miðað við samanburðarhóp. Framsetning mynda var ennfremur villandi par sem eingöngu voru sýnd æxli úr dýrum í meðferðarhópum. Rannsakendur voru heldur ekki blindaðir gagnvart meðferð einstakra dýra. Síðast en ekki síst reyndist ekkert samband vera milli tíðni snemmbærs dauða eða æxlismyndunar og skammta mismunandi meðferða (dose-response relationship). Fjölmargt annað má gagnrýna við pessa rannsókn. Ljóst er að rannsóknin var verulega gölluð og engar marktækar ályktanir hægt að draga af henni.

Opinberir aðilar í Evrópu ákvaðu strax í kjölfar birtingar pessarar vísindagreinar og fjölmiðlaumfjöllunar að leggja sjálfstætt mat á niðurstöður rannsóknarinnar. Til pess verks voru fengnir virtir opinberir eftirlitsaðilar: Evrópska matvælaeftirlitsstofnunin (EFSA) og pýska eftirlitsmiðstöðin, Bundesinstitut für Risikobewertung (BfR). Fyrstu álit pessara opinberu eftirlitsstofnana voru birt tæpum tveimur vikum eftir útgáfu greinarinnar og voru óvenju afdráttarlaus. Báðar stofnanirnar sögðu að vegna alvarlegra ágalla á rannsókninni væri ekki hægt að draga neinar vísindalegar ályktanir og pví engin ástæða til að endurskoða leyfisveitingar fyrir erfðabreyttar plöntur af peirri gerð er um ræddi, né endurskoða leyfisveitingar fyrir illgresiseyðinum glyfosat. ${ }^{2,3}$

Eftir slíka útreið mætti ætla að áhrif svo meingallaðrar vísindarannsóknar myndu skjótt pverra. Svo er pó ekki. Áhrifin má enn greina víða um heim og einnig hér heima. Neytendasamtökin á Íslandi hafa nú tekið höndum saman við MATVÍS (félag iðnaðarmanna í matvæla- og veitingagreinum), Náttúrulækningafélag Íslands, Slow Food samtökin og vottunarstofuna Tún og sent opið bréf par sem skorað er á stjórnvöld að stöðva leyfisveitingar til útiræktunar á erfðabreyttum plöntum hér á landi par til fram hefur farið gagnger endurskoðun á regluverki slíkra leyfisveitinga. Pessháttar krafa til stjórnvalda frá jafn mikilvægum samtökum og Neytendasamtökin eru, hlýtur að vekja furðu. Ekki er pó ólíklegt að slíkar kröfur muni hljóta hljómgrunn hjá einhverjum stjórnmálamönnum. Á Alpingi hefur prívegis verið lögð fram pingsályktunartillaga um bann við útiræktun erfðabreyttra plantna, nú síðast á yfirstandandi haustpingi. Prátt fyrir endurtekin og rökstudd andmæli stórs hóps vísindamanna frá öllum helstu háskóla- og rannsóknarstofnunum á pessu sviði á landinu, nú síðast með undirskriftum um 50 vísinda- manna, hafa umræddir pingmenn aldrei leitað álits pessara sömu fræðimanna.

Framfarir í landbúnaði og matvælaframleiðslu eru aðkallandi á tímum fjölgunar mannkyns, aukinna krafna um sjálfbærni, viðhalds líffræðilegrar fjölbreytni og takmörkunar á ræktarlandi. Notkun erfðatækni til erfðabreytinga er eitt af mörgum tólum sem vísindamenn á pessu sviði beina sjónum sínum að. Erfðabreytingar beinast meðal annars að pví að auka næringargildi ýmissa nytjaplantna, draga úr pörf á skordýraeitri eða öðrum hugsanlegum eiturefnum og auka pol gegn ýmsum meinvaldandi sýkingum, svo dæmi séu nefnd. Virt fræðasamtök og opinberar eftirlitsstofnanir hafa ítrekað ályktað аð erfðabreyttar plöntur séu í sjálfu sér ekki hættulegar umhverfi eða heilsu. Erfðabreytingar eru einvörðungu tól og pau er bæði hægt að nota til góðra og slæmra verka. Рað á að vera keppikefli allra að tryggja að við nýtum okkur pessa öflugu tækni með ábyrgum hætti, sem tryggir um leið öruggari matvælaframleiðslu. Að vilja útiloka eitt áhald úr verkfærakistu vísindamanna á pessu sviði lýsir skammsýni. Fræðimenn og sérfræðingar purfa að vera á varðbergi og tryggja að samtök neytenda og opinberir aðilar móti stefnu í pessum málaflokki sem byggir á traustum fræðilegum grunni og ábyrgri framtíðarsýn með umhverfi og heilsu að leiðarljósi.

\section{Heimildir}

1. Séralini GE, Clair E, Mesnage R, Gress S, Defarge N, Malatesta $\mathrm{M}$, et al. Long term toxicity of a Roundup herbicide and a Roundup-tolerant genetically modified maize. Food Chem Toxicol 2012; 50: 4221-31

2. Statement of EFSA. Review of the Seralini et al. (2012) publication on a 2-year rodent feeding study with glyphosate formulations and GM maize NK603 as published online on 19 September 2012 in Food and Chemical Toxicology. European Food Safety Authority. efsa.europa. eu/en/efsajournal/doc/2910.pdf

3. Feeding study in rats with genetically modified NK603 maize and with a gly-phosate containing formulation (Roundup) published by Séralini et al. (2012). BfR-Opinion 037/2012 of 1 October 2012. bfr.bund.de/cm/349/feeding-study-in-rats-with-genetically-modified-nk603-maizeand-with-a-glyphosate-containing-formulation-rounduppublished-bei-seralini-et-al-2012.pdf

Genetically modified plants; a threat to human health?

Magnus K. Magnusson, MD. Professor and Chairman, Department of Pharmacology and Toxicology, Faculty of Medicine, University of Iceland. 